\title{
Downstream Transformation of the Flood-Flow Characteristics within the River-Floodplain System of the Middle Daugava
}

\author{
Dāvis Gruberts \\ Department of Geography and \\ Chemistry \\ Daugavpils University \\ Daugavpils, Latvia \\ davis.gruberts@du.lv
}

\begin{abstract}
A series of 11 experimental hydrological field surveys of the Daugava's flood-flows has been conducted within the river-floodplain system of the Middle Daugava by the Department of Geography and Chemistry, Daugavpils University, in 2007-2017. The field surveys were conducted in a form of real-time Lagrangian drift experiments, which were focused on a continuous tracking and monitoring of pre-selected flood water masses moving along the Middle Daugava River from Krauja to Dunava at the peak of the spring floods. The real-time tracking and monitoring of the selected flood water masses was conducted by applying a manned drifting research platform. It was equipped with a GPS receiver and an echo-sounding device for repeated measurements of the average drift velocity, the channel's depth and geographical position of the platform in relation to its initial location. During the drift experiments, instrumental measurements were performed repeatedly, each 30-60 minutes. The obtained records were then used to analyze downstream changes in main hydraulic characteristics of the surveyed flood-flows. Main results of 9 real-time Lagrangian drift experiments conducted within the Middle Daugava river-floodplain system in 2007-2017 are analyzed and discussed in this paper. Application of the Lagrangian reference frame for the obtained data records revealed the unsteady, spatially varied nature of the surveyed flood-flows and highlighted an overall downstream reduction of their average drift velocities and depths, as they leaved the Baltic Moraine Uplands and entered the East Latvian Lowland downstream from Daugavpils. The Spearman's correlation revealed the strong effect of inter-annual variation of the peak flood discharge and longitudinal gradient of the water surface on the main hydraulic characteristics of the floodflows. Application of the well-known Chézy equation to the obtained data records also revealed its inadequacy for research purposes of this natural river-floodplain system, but also highlighted the importance of other factors (such as the active cross-section area and hydraulic interaction between the river and its floodplain) on the site-by-site variation of the current velocity within the main channel during the floods.
\end{abstract}

Keywords-Daugava, flood-flow, Lagrangian study.

\section{INTRODUCTION}

The river-floodplain system of the Middle-Daugava is the largest natural floodplain area inundated annually by the floodwaters of the Daugava River, not only in Latvia but also along its entire length [1]. It is located in upper part the Naujenes-Jékabpils stretch [2] between Daugavpils and Jersika. In this stretch, the Daugava River leaves the Baltic Moraine Upland area (i.e. the Augšzemes and Latgales Uplands) and enters the East Latvian Lowland (i.e. the Jersika Plain). The downstream shift in fluvial geomorphology results in significant reduction of the riverbed's longitudinal gradient in summer (from about 0,1 to $\left.0,05 \mathrm{~m} \mathrm{~km}^{-1}\right)$. Along with that gradient change, the average depth of the Daugava's valley decreases from 10$15 \mathrm{~m}$ at Daugavpils to 4-6 $\mathrm{m}$ at Dunava, while the width of the valley proportionally increases - from approximately $1 \mathrm{~km}$ at Naujene to $2-4 \mathrm{~km}$ at the Berezovka (Dviete) inlet [2]

These important geomorphological changes significantly affect also the downstream propagation of the flood-flows that enter the complex river-floodplain system of the Middle Daugava downstream from Daugavpils. During the average spring floods, the relative heights of the flood waves decreases from 6,6 $\mathrm{m}$ at Daugavpils to 3,9 $\mathrm{m}$ at Jēkabpils [2].

The peak flood discharges are usually observed in the Daugava River at Daugavpils in late March - mid-April [3]. Significant part of the Daugava's flood discharge is transferred then to the adjacent floodplain areas, which covers more than $200 \mathrm{~km}^{2}$ and are able to temporarily accumulate more than $0,6 \mathrm{~km}^{3}$ of water for a significant period of time, up to three months [1], [4]. Therefore, this river-floodplain system is a natural flood control mechanism that provides important ecosystem services for the downstream towns and municipalities like Livvani, Jēkabpils and Pḷavinas by diminishing the overall flood risks and preventing more frequent and potentially more catastrophic inundation at spring [4].

Since 2007, a series of 11 real-time Lagrangian drift

Print ISSN 1691-5402

Online ISSN 2256-070X

http://dx.doi.org/10.17770/etr2019vol1.4150

(C) 2019 Dāvis Gruberts

Published by Rezekne Academy of Technologies. 
experiments has been conducted within the Middle Daugava's river-floodplain system during the spring floods in order to develop an empirical model that describes downstream propagation and transformation of the floodflows under different hydrological conditions. The socalled Lagrangian reference frame and/or research method (continuous tracking and monitoring of a selected water mass or 'parcel' during its downstream transport [5]), has been systematically applied for the first time in the history of hydrological research in Latvia [6]. Its application allowed conducting the first real-time monitoring surveys of the moving floodwater masses down the Daugava's valley, helped to overcome the logistic constrains related to the field studies of a large inundated river-floodplain area at the peak of the floods, as well as to avoid the scarcity of hydrological stations located in this particular stretch of the Daugava [7].

This study summarises main results of nine realtime Lagrangian drift experiments conducted by the Department of Geography and Chemistry, Daugavpils University, in 2007-2017, highlights and analyses the observed downstream variation of the average drift velocities and the channel's depths of the surveyed flood-flows, and discusses their relation to the peak flood discharges, longitudinal gradients of the water surface, carrying capacity or roughness of the riverbed and other factors.

The main aim of this study was to test empirically the well-known rule (hypothesis) in river hydraulics that the average current velocity depends mainly on the roughness of the riverbed, the average depth of the channel and longitudinal gradient of the water surface [8], [9]. It was also aimed to answer the intriguing question - is it possible to adequately describe the site-by-site variation of the average current velocity of the particular flood-flow within the Middle Daugava river-floodplain system by applying this general model?

\section{Materials and Methods}

The nine real-time Lagrangian drift experiments mentioned in Introduction were conducted on the Middle Daugava River in 2007, 2010, 2011, 2012, 2013, 2014, 2015, 2016 and 2017, respectively, at different hydrological phases (Table 1). Each drift experiment was conducted shortly before or after the peak of the spring floods (usually in mid-April) at different water level and peak flood discharge of the Daugava River at Daugavpils (Fig. 1).

All nine drift experiments were conducted by applying the manned drifting research platform "Aventura" designed at Daugavpils University in 2007 and made of a maritime life-raft and an inflatable boat attached to each other [6]. The drifting research platform was equipped with two floating anchors, an echo-sounding device, a GPS receiver and other field survey equipment, essential for safe and uninterrupted tracking and monitoring of the selected flood water masses down the river during daytime. During most drift experiments, the average drift velocity of the research platform and total drifted distance was measured each 30 minutes by the built-in GPS receiver of the HACH DS-5 multiprobe [6], [10]. It was recorded also manually by using the GARMIN 76 maritime GPS receiver.

The depth of the main channel of the Daugava River at the particular sites was measured also manually by an echo-sounding device "Plastimo ECHOTEST". The depth soundings were performed each 30-60 minutes [6], [10].

The peak flood discharge values in the Daugava River at Daugavpils during the particular drift experiments were obtained from a stage-discharge relationship curve constructed for the hydrological station "DaugavaDaugavpils" (Fig. 2). It was based on the empirical data records of the water level heights and corresponding instant discharges available at the hydrological data archive of the Latvian Environment, Geology and Meteorology Centre (LVGMC). The water level heights at Daugavpils in March, April and May were also obtained from the online information retrieval system of the LVĢMC (Fig. 1).

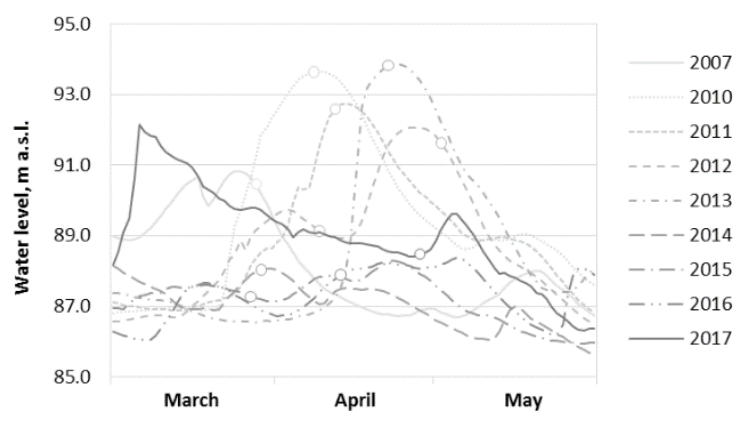

Fig. 1. Fluctuation of water levels in the Daugava River at Daugavpils during the spring floods of 2007-2017 (dates of the drift experiments are marked as empty curves; data source: LVĢMC).

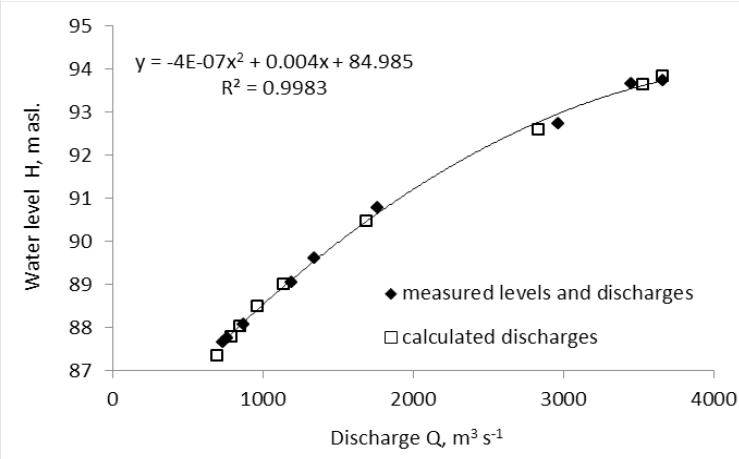

Fig. 2. The stage-discharge relationship curve for the Daugava River at Daugavpils for the spring floods of 2007-2017 (main data source: LVĢMC).

To test the hypothesis mentioned in Introduction, the average current velocities were calculated for each site used for instrumental measurements during the relatively moderate spring floods of 2014, 2015, and 2016 (Table 1). These drift experiments were selected by assuming that during realatively low spring floods the flood-flows of the Daugava River are concentrated mainly within its main channel, and the water mass exchange with the adjacent floodplain downstream from Daugavpils is minimal.

The average current velocities at particular sites $\left(\mathrm{v}_{\mathrm{av}}\right)$ for these moderate flood-flows were calculated by applying the well-known Chézy equation [8]: 


$$
\mathrm{v}_{\mathrm{av}}=\mathrm{C} \sqrt{\mathrm{R} \mathrm{I}}
$$

where

$\mathrm{C}$ - the Chézy's coefficient;

$\mathrm{R}$ - hydraulic radius of the river channel (m);

$\mathrm{I}$ - longitudinal gradient of water surface $\left(\mathrm{m} \mathrm{km}^{-1}\right)$.

The Chézy's coefficients (C) were calculated by applying the Manning's equation [8]:

$\mathrm{C}=\mathrm{R}^{1 / 6} / \mathrm{n}$

where

$\mathrm{n}$ - roughness coefficient of the riverbed that, in this case, was equal to 0,033 [7].

The hydraulic radius (R), which is roughly equal to the average depth of the river [8], was substituted by the actual depth of the main channel recorded in situ. The longitudinal gradients of the water surface (I) were assumed to be constant for the entire length of the drift distance and were calculated as differences per distance $\left(\mathrm{m} \mathrm{km}^{-1}\right)$ between the water level heights at the nearby hydrological stations (i.e. "Daugavpils" and "Vaikulāni”" located $20 \mathrm{~km}$ from each other) on the particular days, which in turn were obtained from the LVĢMC online data archive.

The calculated average current velocity values were then compared to the actually recorded average drift velocities by applying the linear correlation analysis method [8]. The Pearson's correlation coefficients were calculated also between the average velocities and depths of the surveyed flood-flows and the peak flood water discharges and longitudinal water level gradients of the Daugava River at Daugavpils.

\section{RESULTS AND DISCUSSION}

In total, more than 160 series of instrumental data records were obtained in situ, and main hydraulic characteristics of the surveyed flood-flows thus were obtained (Table 1). The correlation analysis revealed strong linear positive correlations of the average drift velocities and the main channel's depths to the inter-annual variation of the peak flood discharges in the Daugava River at Daugavpils (Fig. 3), as well as to the longitudinal water surface gradients between the nearby hydrological stations during the particular drift experiments (Fig. 4).

Graphical analyis of the recorded data records plotted on the distance axis showed that the flood-flows of the Daugava River must be classified as unsteady, turbulent and spatially varied flows [9], since their average velocity and depth changes abruptly from site to site over a relatively short distance (Fig. 5, 6). There are also certain downstream trends visible, especially during the relatively large spring floods of 2010, 2011 and 2013 - i.e. a gradual decrease of the recorded average drift velocity and the channel's depth en route. Such trends have been stated and described already after the second real-time Lagrangian drift experiment on the Middle Daugava River conducted on April 8, 2010 [10].

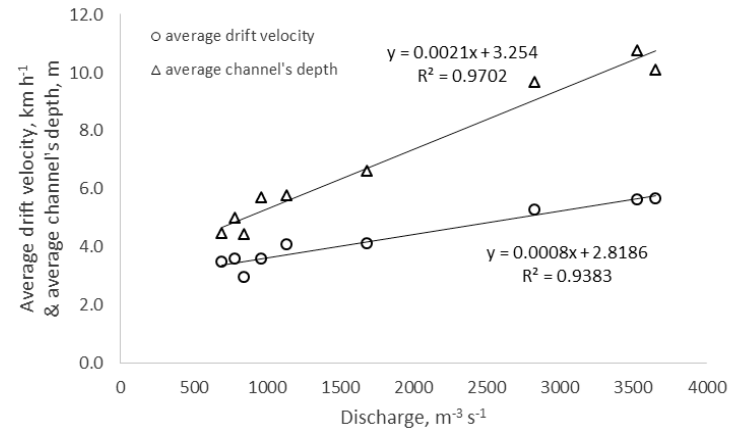

Fig. 3. Correlation of the average drift velocities and depths to the peak flood discharges of the Daugava River at Daugavpils.

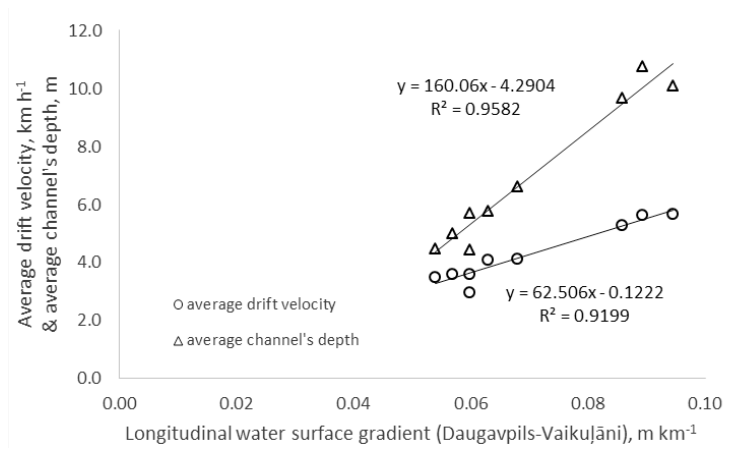

Fig. 4. Correlation of the average drift velocities and depths to the longitudinal water surface gradients of the Daugava River between Daugavpils and Vaikuḷāni.

However, in the case of the particular flood-flows, there were no significant correlations stated between the average drift velocities and actual channel's depths, except for some rare cases, like on March 28, 2007 (Table 1). This lack of correlation obviously indicates that the observed downstream variation of the average drift velocity for this particular stretch of the Daugava River is controlled by some other factors instead of the depth of the main channel.

Correlation analyis revealed also a large gap between the actually recorded average drift velocities obtained during the relatively low or moderate spring floods of 2014, 2015 and 2016, and the theoretically calculated average current velocities for these cases (Fig. 7).

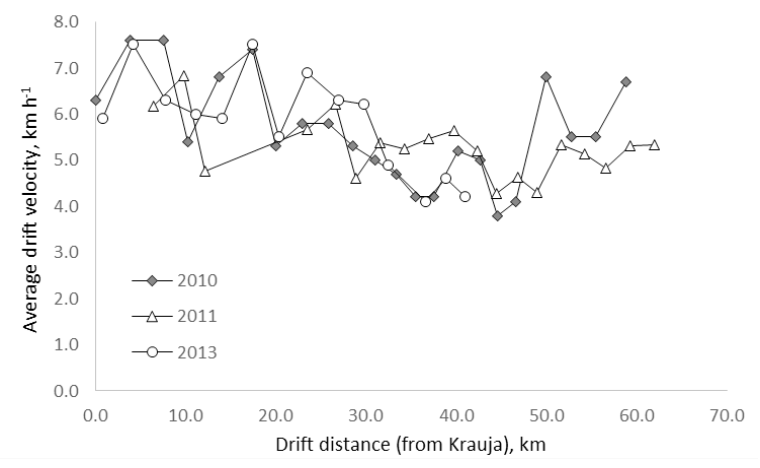

Fig. 5. Variation of the average drift velocity in the Daugava River downstream from Krauja during the spring floods of 2010, 2011 and 2013. 


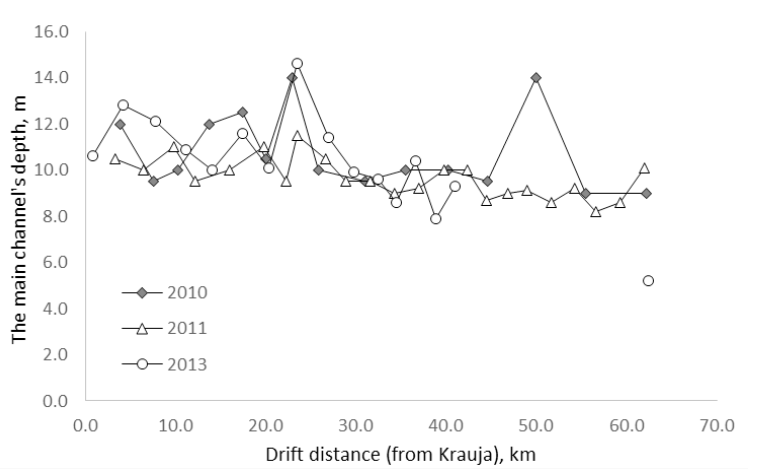

Fig. 6. Variation of the main channel's depth in the Daugava River downstream from Krauja during the spring floods of 2010, 2011 and 2013 .

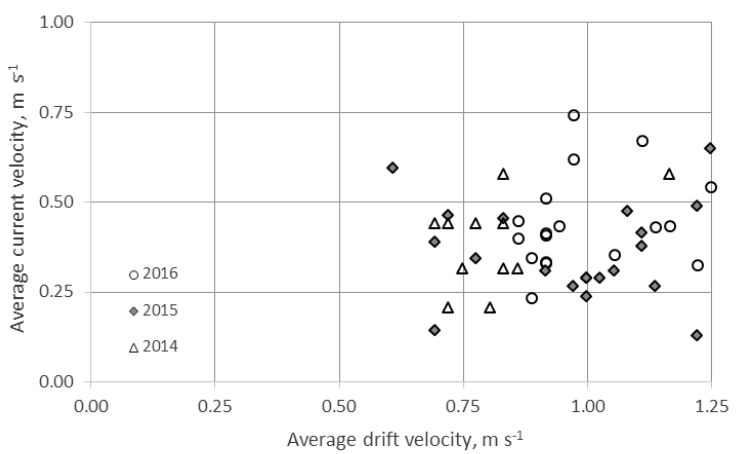

Fig. 7. Correlation between the calculated average current velocities and the recorded drift velocities during the spring floods of 2014, 2015 and 2016.

Even by taking into account an assumption that the recorded drift velocities represent the maximum velocities of the surveyed flood-flows (and therefore must be multiplied by 0,6 in order to obtain the corresponding average current velocity values [8]), they are nevertheless about $30 \%$ higher than those calculated theoretically by applying the Chézy equation (Fig. 7). Such discrepancy probably indicates that actual carrying capacities of the Middle Daugava's main channel during the spring floods are at least $30 \%$ higher than those calculated theoretically.

On the other hand, there was almost no correlation found between these two velocity characteristics (Fig. 7). Obviously, it must be attributed to the actual depth data soundings which were used in this study to substitute the average depth (hydraulic radius) of the river channel in the classic Chézy's and Manning's equations. Therefore, the Lagrangian data records of the actual depths could not be directly used with these formulas to adequately describe site-by-site variation of the average current velocities within the main channel of the Middle Daugava riverfloodplain system. Similar conclusions have been drawn from other experimental studies of the river-floodplain systems, too [11].

Therefore, the average current velocities of the surveyed flood-flows and their site-by site variation within the Middle Daugava river-floodplain system during the moderate floods could not be explained by an impact of a single driving factor, such as the depth of the main channel. Other factors included in the Chézy's equation should be analysed also.

The first driving factor - the carrying capacity or roughness of the riverbed at the particular site, is physically related to the morphology of the riverbed, its roughness or smoothness and/or sizes and shapes of underwater obstacles [8], as well as to the channel's active crosssection area [9].

In the case of the low-to-moderate flood-flows, which are constricted mostly to the main channel of the Daugava River, the principle of continuity must be in force if the discharge remains constant [9]. In other words, if the velocity goes down, the size of the cross-section area goes up, and vice versa. The active cross-section area in turn depends on the average depth and width of the channel. In our case, the actual depths of the main channel slightly decreased during the drift experiments in 2014 and 2015, or remained almost constant in 2016 (D. Gruberts, unpublished data). Therefore, it is right to assume that the width of the Daugava's main channel and the active crosssection area of the flood-flows simultaneously increased in order to compensate overall reduction of the drift velocities and the channel's depths down the river (Fig. 5, 6).

Possible impact of the second factor (i.e. the site-by-site variation of the longitudinal gradient) could not be verified jet because of the lack of detailed information regarding the heights of the water surface at particular sites along the main channel of the Middle Daugava on the particular days. In theory, the current velocity must decrease along with reduction of the longitudinal gradient of the water surface. It must be true also in this case because the longitudinal gradient of the riverbed of the Daugava River at summer gradually decreases downstream from Daugavpils (J. Soms, unpublished data). To some extent such reduction could also be stated from the historic flood water level data records obtained at corresponding hydrological stations, i.e. "Krāslava", "Daugavpils", "Vaikul̦āni" and "Jersika" [7]. These hydrological stations are too few and located too far from each other, however, in order to use their actual daily data records for calculation of the longitudinal gradients at particular sites along the river channel.

In the case of relatively large spring floods such as those recorded in 2010, 2011 and 2013, there is another very important driving factor not mentioned before - an active hydraulic interaction between the main channel and the adjacent floodplain. The hydraulic interaction between the river and its floodplain, as well as its physical impact on spatial variation of the average current velocity, is still poorly understood due to the lack of direct observations in situ. In general, four main stages of such interaction and their hydrological effects have been identified by laboratory experiments [11]:

(a) actively interacting, sub-parallel flood-flows within the river and the adjacent floodplain - the average current velocity within the main channel decreases by $8-10 \%$ when compared to laterally isolated floodflows;

(b) active movement of the floodwaters from the river to the floodplain - the current velocity within the main channel increases by $10-20 \%$;

(c) active movement of the floodwaters from the floodplain back to the river - the current velocity within the main channel decreases significantly due to turbulent mixing (by $>40 \%$ );

(d) the dynamic axis of the flood-flows crosses at wide angle $\left(>10^{\circ}\right)$ - the water carrying capacity of the main channel and the average current velocity within it de- 
creases drastically, and even negative velocity values could be observed.

Since during the spring floods the riverbed and adjacent floodplain of the Middle Daugava River do actually interact with each other by exchanging large volumes of water at particular sites, especially at the Berezovka (Dviete) River inlet [12], this factor must have also a profound effect on the site-by-site variation of the average current velocities within the main channel. Its role and action could be best analysed by applying the geospatial methods (such as the ArcGIS tools) to the obtained Lagrangian data records, which is outside the scope of this study, however. Geospatial analysis of these hydrological processes and their effects is the next logical step in hydrological research of this large lowland river-floodplain system.

\section{Conclusions}

Application of the Lagrangian research method in annual hydrological field surveys of the largest riverfloodplain system in Latvia provided first insight into the real-time processes of downstream transformation of the main hydraulic characteristics of the Daugava's floodflows that are specific to this stretch of the river, and highlighted the complex nature of their inter-annual and site-by-site variation.

In general, the average current velocities and actual depths of the surveyed flood-flows of the Daugava River are dictated by the inter-annual variation in the peak flood discharge and longitudinal gradient of the water surface downstream from Daugavpils.

In this stretch of the Daugava River valley, where it enters the East Latvian Lowland, the average current velocities and actual depths of the flood-flows are gradually reduced downstream, most probably, due to the corresponding significant increase of the active crosssection area (in the case of moderate spring floods) and/ or active hydraulic interaction between the main channel and the adjacent floodplain (in the case of relatively large spring floods).

The well-known Chézy's equation could not be successfully appied along with the Largrangian experimental data records to calculate the average current velocities even for the moderate flood-flows, since the actual depth soundings do not represent the average depths of the main channel at the particular sites. Therefore, it is not possible to adequately describe the observed site-bysite variation of the average drift velocity of the particular flood-flow within the Middle Daugava river-floodplain system by applying this general model, and geospatial analysis methods must be applied instead.

\section{REFERENCES}

1. A. Škute, D. Gruberts, J. Soms and J. Paidere, "Ecological and hydrological functions of the biggest natural floodplain in Latvia". Ecohydrol. \& Hydrobiol., vol. 8 (2-4), pp. 291-306, 2008.

2. G. J. Eberhard, Srojenije i razvitije dolin basseina reki Daugava. Riga: Zinatne, str. 48-49, 1972. (in Russian)

3. V. F. Loginov i G. J. Segal' (red.) Zapadnaja Dvina - Daugava. Reka i vremja. Minsk: Belorusskaja nauka, str. 6-44, 2006. (in Russian)

4. D. Gruberts and K. Vilcāne, "Floodwater storage capacity of the Middle Daugava floodplain". Environment. Technology. Resources. Proceedings of the 10th International Scientific and Practical Conference. Vol. II, pp. 112-115, 2015.

5. M. W. Doyle and S. H. Ensign, "Alternative reference frames in river system science”. BioScience, vol. 59, pp. 499-510, 2009.

6. D. Gruberts, J. Paidere, A. Škute and I. Druvietis, "Lagrangian drift experiment on a large lowland river during a spring flood". Fundam. Appl. Limnol, vol. 179/4, pp. 235-249, 2012.

7. Gosudarstvennyj vodnyj kadastr. Tom X. Latvijskaja SSR.. Mnogoletnye dannye o rezhime i ressursah poverhnosnyh vod sushi. Leningrad: Gidrometeoizdat, str. 23-244, 1987. (in Russian)

8. B. Sarma, Hidrometrija, hidrologija un noteces regulēšana. Rīga: Zvaigzne, 32.-33. lpp., 1990.

9. N. D. Gordon, T. A. McMahon, B. L. Finlayson, C. J. Gippel and R. J. Nathan, Stream Hydrology. An Introduction for Ecologists. $2^{\text {nd }}$ ed. John Wiley \& Sons Ltd., pp. 155-168, 2004.

10. D. Gruberts and J. Paidere, "Lagrangian drift experiment on the Middle Daugava River (Latvia) during the filling phase of the spring floods". Fundam. Appl. Limnol. 184 (3), pp. 211-230, 2014.

11. N. V. Baryshnikov, Rechnye pojmy. Leningrad: Gidrometeoizdat, str. 64-134, 1978. (in Russian)

12. L. I. Glazacheva, Ledovoj i termicheskij pezhim rek i ozer Latvijskoj SSR. Uchenye zapisi. Geograficheskije nauki. Tom 65. Riga: Zinatne, str. 118, 1965 (in Russian)Table 1. Summary of the main results of the 9 real-time Lagrangian drift experiments conducted on the Middle Daugava River in 2007-2017

\begin{tabular}{|l|c|c|c|c|c|c|c|c|c|}
\hline Date of the drift experiment (dd/mm/yyyy) & $\mathbf{2 8 / 0 3 / 2 0 0 7}$ & $\mathbf{0 8 / 0 4 / 2 0 1 0}$ & $\mathbf{1 2 / 0 4 / 2 0 1 1}$ & $\mathbf{1 0 / 0 4 / 2 0 1 2}$ & $\mathbf{2 2 / 0 4 / 2 0 1 3}$ & $\mathbf{2 9 / 0 3 / 2 0 1 4}$ & $\mathbf{2 6 / 0 3 / 2 0 1 5}$ & $\mathbf{1 2 / 0 4 / 2 0 1 6}$ & $\mathbf{2 8 / 0 4 / 2 0 1 7}$ \\
\hline Hydrological phase & drainage & filling & filling & drainage & filling & filling & drainage & filling & drainage \\
\hline $\begin{array}{l}\text { Water level of the Daugava River at } \\
\text { Daugavpils, } \mathrm{m} \text { a.s.l. }\end{array}$ & 90.5 & 93.6 & 92.6 & 89.0 & 93.8 & 88.0 & 87.4 & 87.8 & 88.5 \\
\hline $\begin{array}{l}\text { Discharge in the Daugava River at } \\
\text { Daugavpils, } \mathrm{m}^{3} \mathrm{~s}^{-1}\end{array}$ & 1688 & 3530 & 2831 & 1137 & 3659 & 845 & 696 & 787 & 965 \\
\hline Total drifted distance, km & 51.3 & 62.2 & 61.9 & 44.9 & 62.4 & 24.2 & 35.5 & 32.3 & 41.2 \\
\hline Total drift time, hh:mm & $12: 00$ & $11: 00$ & $11: 00$ & $10: 30$ & $11: 00$ & $08: 30$ & $10: 00$ & $09: 00$ & $10: 00$ \\
\hline Average drift velocity, km $\mathrm{h}^{-1}$ & 4.1 & 5.6 & 5.3 & 4.1 & 5.7 & 2.9 & 3.5 & 3.6 & 3.6 \\
\hline $\begin{array}{l}\text { Average depth of the main channel, } \\
\mathrm{m}\end{array}$ & 6.6 & 10.8 & 9.7 & 5.8 & 10.1 & 4.4 & 4.5 & 5.0 & 5.7 \\
\hline $\begin{array}{l}\text { Average longitudinal gradient of } \\
\text { the flood water level (Daugavpils- } \\
\text { Vaikul,āni), } \mathrm{m} \text { km }\end{array}$ & 0.07 & 0.09 & 0.09 & 0.06 & 0.09 & 0.06 & 0.05 & 0.06 & 0.06 \\
\hline $\begin{array}{l}\text { Pearson's correlation coefficient } \\
\text { between the average drift velocity } \\
\text { and the main channel's depth, } \mathrm{r}\end{array}$ & 0.96 & 0.50 & 0.66 & 0.54 & 0.74 & 0.45 & -0.03 & 0.22 & 0.55 \\
\hline
\end{tabular}

